\title{
RT-PCR 法を用いた新生児エンテロウイルス髄膜炎の検討
}

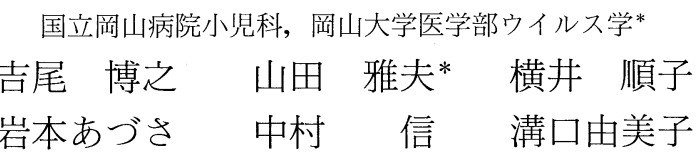

(平成 9 年 6 月 4 日受付)

(平成 9 年 7 月 11 日受理)

Key words: enterovirus, meningitis, reverse transcription-polymerase chain reaction, neonate, cerebrospinal fluid

\begin{abstract}
要旨
新生児エンテロウイルス感染症41例について, Reverse transcription-polymerase chain reaction (RT-PCR) 法を用いた䯣膜炎の診断を含め検討した。髄膜炎の診断を髄液培養陽性，髄液細胞数増加あ るいは髄液 RT-PCR 法陽性のいずれかを満たす場合とすれば，少なくとも31例（76\%）が髄膜炎と診断 された。髄液培養陽性は 14/28(50\%) 例で，内10例がRT-PCR 法により検索可能で全例陽性であった。 髄液細胞数増加例では RT-PCR 法陽性は 18/20（90\%）例であった。髄液培養陰性例あるいは髄液細胞 数の増加を認めなかった例でRT-PCR 法陽性例は，それぞれ 6/13（46\%）例，5/14（36\%）例であり， 髄液培養陰性で且つ髄液細胞数増加がなくRT-PCR 法陽性は1/6（17\%）例であった。RT-PCR 法は新 生児エンテロウイルス髄膜炎の診断においても従来法と比較して感受性, 特異性が高く, 迅速性があり 患児をfollowする上でも有用と考えられた。
\end{abstract}

\section{序 文}

エンテロウイルス $(\mathrm{EV})$ は乳幼览のウイルス感 染症の中では，髄膜炎を最もよく起こすウイルス として知られている(1) 3). 特に新生児においては $\mathrm{EV}$ 髄膜炎の発生頻度が高いと言われている4 た他のウイルス疾患や細菌感染とも鑑別が困難な こともあり，その診断は正確になされるべきであ る ${ }^{5) ~ 8)}$. 従来よりウイルス性髄膜炎の診断は髄液 細胞数 (白血球数) およびウイルス分離を中心に なされてきたが910), 今回我々は, Reverse Transcription Polymerase Chain Reaction (RT-PCR) 法を用いて新生児の $\mathrm{EV}$ 髄膜炎の診断について検 討したので報告する。

\section{対象と方法}

対象は平成 3 年 4 月から平成 8 年 6 月までに発 熱等を主訴に当院 NICUに入院しウイルス感染

別刷請求先：(广700) 岡山市南方 $2-13-1$ 国立岡山病院小児科吉尾 博之
が考えられた新生児の内，患児の咽頭，尿，便㧍 よび髄液のいずれかより EV（ゲノムを含む）が分 離され $\mathrm{EV}$ 感染症と診断した41例である。この内 34 例が髄液保存 $\left(-70^{\circ} \mathrm{C}\right)$ してあり全例に EV を 対象としたRT-PCR 法を行い, 髄液培養および髄 液細胞数所見と比較検討した。

髄液中のウイルス RNA の抽出は, 髄液 $500 \mu 1$ をフェノール，クロロホルム処理後エ夕ノール沈 殿法にて行い, $20 \mu 1$ の蒸留水に溶解した後 $2 \mu 1$ を RT-PCR 法に用いた. RT-PC̣R 法は GeneAmp ${ }^{\circledR}$ RNA-PCR kit (TAKARA)を用いて行った. RT および PCR 反応に用いたプライマーは Rotbart らが指定した $5^{\prime}$-non-coding regionのエンテロウ イルスの共通領域にそれぞれ設定した ${ }^{11)}$. 即ち塩 基配列 は5'-CCTCCGGCCCCTGAATGCGGCTAAT-3' (センスプライマー) おょ び 5'ATTGTCACCATAAGCAGCAGCCA-3' (アンチセンス プライマー), インナープライマーとして5'-GAA- 
Fig. 1 Detection of enterovirus genome from the neonatal CSF by single RT (lanes 1 to 5) and nested (lanes 6 to 10 ) PCR. Lanes 2, 7 ; patient 1, lanes 3, 8; patient 2 , lanes 4,9 ; patient 3 , lanes 5,$10 ; 3$ days after dropping fever of patient 1, lanes 1, 6; positive control, M ; marker ( $\Phi$ X174/Hinf I digests), N : negative control.

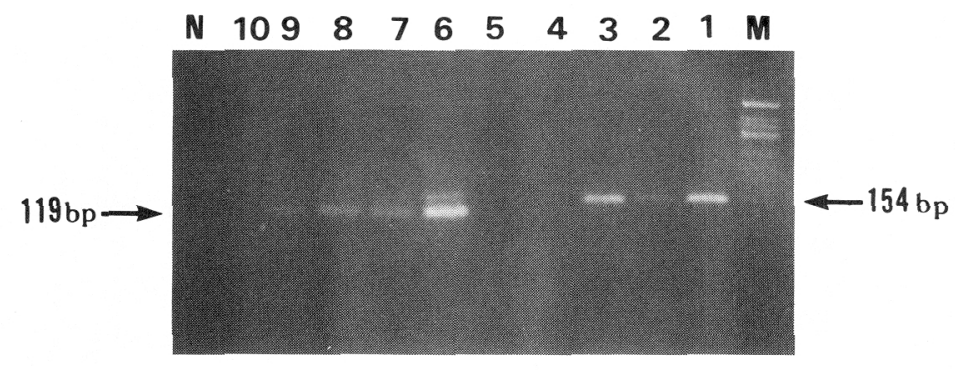

ACACGGACACCCAAAGTA-3’（アンチセンス プライマー)である。増幅反応の条件は denature, $94^{\circ} \mathrm{C} ; 1$ 分, annealing, $57^{\circ} \mathrm{C} ; 2$ 分 extension, $72^{\circ} \mathrm{C} ; 2$ 分で30cycle 行った。 PCR 産物はエチジ ウムブロマイド含有 $3 \%$ アガロースゲルで電気泳 動を行い single, nested PCR それぞれ154bp およ び $119 \mathrm{bp}$ の特異的バンドの検出を行った。

臨床的な髄膜炎の診断として髄液細胞数の増加

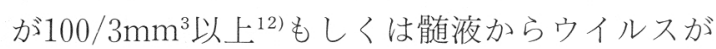
分離された場合とした。ウイルス分離は，多くは SRL に依頼したが，MK (monkey kidney) 細胞 および HEL (human embryonic lung fibroblast) 細胞を用い同定は中和法により行った。

\section{成 績}

Fig. 1 にRT-PCR 法の結果例を示した。有熱 期であっても single RT-PCR 法だけでは特異バ ンドを検出できないことがあり, nested PCR 法 によって検出可能であった。解熱 3 日後 (Lane 10）は nested PCR 法でも検出できなかった。

Table 1 EV 感染症例を示した。分離ウイル スはコクサッキー群14例(B1；2，B2；1，B3； 1, B4；5, B5； 5 ), エコー群18例 ( 3 型；1, 6 型； $3 ， 9$ 型；1，11型； 2, 14型，1，19型； 1，25型；3，30型；6), ウイルスは分離された が型同定不能例は 2 例であった。これらの内，髅 液よりウイルスが分離されたのは14例(50\%)で あった。また髄液細胞数増加を認めたのは24例 (59\%)であった。これに対し RT-PCR 法陽性は
23例（68\%）であった。以上の結果から髄膜炎の 診断を髄液培養陽性, 䯣液細胞数増加あるいは髄 液 RT-PCR 法陽性のいずれかを満たす場合とす れば 31例(76\%) が髄膜炎と診断された。

Table 2 に髄液培養，髄液細胞数，RT-PCR 法 との関係を示した。髄液培養陽性例では RT-PCR 法も全例陽性に対し, 髄液培養陰性例でも6/ 13 (46\%) にRT-PCR 法が陽性であった。髄液細 胞数増加例では, 2 例に RT-PCR 法が陰性で, 培 養および細胞数共に陰性例では 1 例に RT-PCR 法陽性が認められた。

\section{考察}

$\mathrm{EV}$ 感染症は新生児のウイルス感染症の中でも 最も高頻度に発症し, 比較的予後良好例が多いも のの，時に重症化し死亡することもあり注意すべ き感染症である。また髄膜炎は高頻度に合併する ため, 新生児期の $\mathrm{EV}$ 髄膜炎の診断は，上り正確 になされることが必要である。EV髄膜炎に対す るPCR 法の開発が最近報告されたが，従来から の髄液培養, 髄液細胞数の増加等で行われている 髄膜炎の䛦断に比へ感受性，特異性共に優れてい ると考えられる13114)。今回著者らが行った結果で も PCR 法を加えることにより, $\mathrm{EV}$ 感染症で最終 的に髄膜炎を合併していたと考えられたのは76\% であり，これは従来より考えられていた $50 \%$ とい う数字よりかなり高い值であった 。これは新生 児期に EV 感染症を疑った場合，極めて高い確率 で髄膜炎を合併していると考えるべきである。 
Table 1 Cases of neonatal enteroviral infection

\begin{tabular}{|c|c|c|c|c|c|c|c|}
\hline \multirow{2}{*}{ Case } & \multirow{2}{*}{ Day } & \multirow{2}{*}{ Sex } & \multicolumn{2}{|c|}{ Isolated virus } & \multirow{2}{*}{$\begin{array}{l}\text { Initial CSF } \\
\text { cells }(/ 3 \mu 1)\end{array}$} & \multirow{2}{*}{$\underset{\text { (CSF) }}{\text { RT-PCR }}$} & \\
\hline & & & other than CSF & $\mathrm{CSF}$ & & & \\
\hline 1 & 7 & M & Coxsackie B 2 & Coxsackie B 2 & 624 & + & \\
\hline 2 & 6 & $\mathrm{~F}$ & Coxsackie B 3 & N.D. & 1,280 & + & \\
\hline 3 & 2 & $\mathrm{~F}$ & Coxsackie B 4 & Coxsackie B 4 & 7,740 & + & \\
\hline 4 & 4 & M & Coxsackie B 5 & Coxsackie B 5 & 6 & + & \\
\hline 5 & 16 & $\mathrm{~F}$ & Coxsackie B 5 & N.D. & 2,368 & + & \\
\hline 6 & 7 & $\mathrm{~F}$ & Coxsackie B 5 & Coxsackie B 5 & 4,963 & + & \\
\hline 7 & 2 & $\mathrm{M}$ & Echo14 & - & 922 & + & \\
\hline 8 & 24 & $\mathrm{~F}$ & Echo30 & Echo30 & 310 & + & \\
\hline 9 & 7 & $\mathrm{~F}$ & Echo6 & - & 3,200 & + & \\
\hline 10 & 25 & $\mathrm{~F}$ & Echo9 & Echo9 & 38 & + & \\
\hline 11 & 6 & M & N.D. & - & 600 & + & \\
\hline 12 & 16 & $\mathrm{M}$ & Subtype unknown & N.D. & 10 & + & \\
\hline 13 & 6 & $\mathrm{M}$ & Subtype unknown & N.D. & 510 & + & \\
\hline 14 & 3 & $\mathrm{~F}$ & - & Echo11 & 70 & + & \\
\hline 15 & 8 & F & - & Coxsackie B 1 & 680 & + & \\
\hline 16 & 8 & $\mathrm{M}$ & - & Coxsackie B 4 & 6,000 & + & \\
\hline 17 & 24 & $\mathrm{~F}$ & - & Coxsackie B 5 & 11,400 & + & \\
\hline 18 & 7 & $\mathrm{~F}$ & - & - & 800 & + & \\
\hline 19 & 2 & $\mathrm{M}$ & - & N.D. & 750 & + & \\
\hline 20 & 3 & $\mathrm{~F}$ & - & - & 1 & + & \\
\hline 21 & 2 & F & - & N.D. & 144 & + & \\
\hline 22 & 5 & $\mathrm{~F}$ & - & N.D. & 1,000 & + & \\
\hline 23 & 9 & $\mathrm{M}$ & - & - & 340 & + & \\
\hline 24 & 5 & $\mathrm{M}$ & Coxsackie B 1 & - & 26 & - & \\
\hline 25 & 4 & $\mathrm{~F}$ & Coxsackie B 4 & - & 5 & - & \\
\hline 26 & 5 & $\mathrm{~F}$ & Coxsackie B 4 & - & 8 & - & \\
\hline 27 & 9 & $\mathrm{~F}$ & Coxsackie B 5 & N.D. & 25 & - & \\
\hline 28 & 29 & M & Echo25 & N.D. & 5 & - & \\
\hline 29 & 12 & $\mathrm{M}$ & Echo25 & - & 10 & - & \\
\hline 30 & 2 & $\mathrm{~F}$ & Echo25 & N.D. & 32 & - & \\
\hline 31 & 7 & M & Echo3 & - & 30 & - & \\
\hline 32 & 27 & $\mathrm{~F}$ & Echo30 & - & 160 & - & \\
\hline 33 & 8 & M & Echo6 & - & 670 & - & \\
\hline 34 & 13 & $\mathrm{~F}$ & Echo6 & N.D. & 0 & - & \\
\hline 35 & 16 & M & Coxsackie B 4 & Coxsackie B 4 & 1,908 & N.D. & \\
\hline 36 & 3 & $\mathrm{~F}$ & Echo19 & Echo 19 & 0 & N.D. & DIC, death \\
\hline 37 & 24 & $\mathrm{~F}$ & Echo30 & N.D. & 186 & N.D. & \\
\hline 38 & 7 & M & Echo30 & N.D. & 1,121 & N.D. & \\
\hline 39 & 14 & $\mathrm{~F}$ & Echo30 & Echo 30 & 1,378 & N.D. & \\
\hline 40 & 13 & M & Echo30 & - & 19 & N.D. & \\
\hline 41 & 6 & M & - & Echo 11 & 32 & N.D. & DIC \\
\hline
\end{tabular}

Table 2 Sensitivity and specificity of RT-PCR for neonatal enterovirus meningitis

\begin{tabular}{lcc}
\hline & RT-PCR $(+)$ & RT-PCR $(-)$ \\
\hline culture $(+)$, cells in $\operatorname{CSF}(>100 / 3 \mu 1)$ & 7 & 0 \\
culture $(+)$, cells in $\operatorname{CSF}(<100 / 3 \mu 1)$ & 3 & 0 \\
culture $(-)$, cells in $\operatorname{CSF}(>100 / 3 \mu 1)$ & 5 & 2 \\
culture $(-)$, cells in CSF $(<100 / 3 \mu 1)$ & 1 & 5 \\
\hline
\end{tabular}


従来よりウイルス性髄膜炎の診断は髄液からの ウイルス分離あるいは髄液細胞数の増加を基に行 われているが，一般病院で至適条件でウイルス分 離，同定を行うのは困難で，現状では専門施設に 検体を送らざるを得ない。また検体の時間的およ び物理的保存にも限界があるため, 分離率は当然 低下する。また RNase の存在により，髄液中のウ イルスカ価は低下しやすいことも影響する ${ }^{1516)}$. 今回の我々の検討も，過去のウイルス分離デー夕 が多く,何らかの検体からの分離率が 34/41(83\%) 例で，髄液培養施行例での陽性例は 14/24(50\%) とやや低值となった。今後一般病院においても， ウイルスを含めた微生物検出体制の充実が望まれ る。

髄液細胞数については, 増加が認められれば髄 膜炎の診断は容易であるが，増加が認められない 場合でも直ちに髄膜炎を否定できない所に髄膜炎 の診断の難しさがある。特に新生児の場合，病的 発熱と診断されれば早期に髄液検査を含めた septic work up を行うことが多いが, 急性期の検査 で髄液細胞数の増加が認められず再度の検査にて 増加を認め, 髄膜炎と診断できる症例が少なから ず存在する.今回の検討例でも少なくとも 3 例は, 初回髄液細胞数の増加を認めず，ウイルス分離, RT-PCR 法共に陽性であった。このような症例に 対して, RT-PCR 法を効率よく導入することは, 医学的に正確に迅速診断ができるのみならず, less invasive care という観点からも，患児にとつ て極めて有益と思われる。新生児の髄液 PCR 法 を行う際に注意する点としては，新生児の髄液は 年長児と比べ一般に蛋白濃度が高いこと, 更に髄 液穿刺の際に小さいが故に血液の混入が起こりや すいことなどがあり，これらの蛋白，へモグロビ ンなどが PCR の inhibitor として働く可能性が あるため，検体前処置は慎重に行う必要がある. また, 血液の混入が多い場合には, PCR 法の結果 が髄液あるいは血液のどちらの結果を反映してい るのか, 対象ウイルスによっては判断に苦慮する ことも考えられ，このような検体は，当然ながら 髄液 PCR には不適当である.

今回の検討では髄液細胞数増加群で 18/
20 (90\%) に RT-PCR 法が陽性であったが，2 例 は陰性であった。一般に髄液細胞数増加があれば ウイルスが分離される確率が高く，ウイルスゲ， ムも多く存在し RT-PCR 法も陽性と成りやすい と考えられるが，この 2 例が陰性であったのは RT-PCR 法自体の感度の問題か，もしくは検体が 比較的古いために，ウイルスゲノムの保存状態が 不良であった可能性等が考えられる，EVに対す る RT-PCR 法の感度は,ハイブリダイゼーション 法を組み合わせることにより 3 ～10倍感度が上が $\eta^{17)}, 10^{3} \mathrm{TCID}_{50}$ (50\%tissue culture infectious dose）程度と考えられるが ${ }^{11)}$ ，今回我々はアイソ トープの使用ができないため, nested PCR 法を 用いた。また実際に用いた nested PCR 法の感度 測定は行っていないが，この方法にてもハイブリ ダイゼーション法と同程度の感度が期待できると 思われる.今回の結果では, 髄液 RT-PCR を行っ た場合，有熱期の髄液であっても多くは nested PCR 法によって診断可能であり，また解熱後に再 度髄液を採取できた例では nested PCR は陰性で あった。これらのことから新生児の $\mathrm{EV}$ 髄膜炎で は解熱後，急速に髄液からウイルスが排除される のではないかと思われる。

新生児の EV 髄膜炎の診断に RT-PCR 法は従 来法より感度，特異性に優れており，正確で迅速 な診断に結びつくことは，医学的に不要な検査， 治療の省略につながると考えられる，現在 RTPCR 法は特殊な検査設備を必要とするが，より簡 便な PCR 法も開発されつつあり, 近い将来攵， 厶診断がより身近で行われることが期待される.

\section{文献}

1) Cherry JD: Aseptic meningitis and viral meningitis. In: Feigin RD, Cherry JD, eds. Textbook of pediatric infectious disease. 3rd edition. 439-445, Saunders, Philadelphia, 1992.

2) Nogen AG, Lepow ML: Enteroviral meningitis in very young infants. Pediatrics $1967 ; 40$ : 617-625.

3) Miller DG, Gabrielson MO, Bart KJ, Opton EM, Horstmann DM: An epidermic of aseptic meningitis, primarily among infants, caused by echovirus 11-prime. Pediatrics 1968; 41 : 77-90.

4) Krajden S, Middleton PJ: Enterovirus infec-

平成 9 年 10 月 20 日 
tions in the neonate. Clin Pediatr 1983 ; $22: 87$ 92.

5) Jarvis WR: Echovirus type 7 meningitis in young children. Am J Dis Child 1981; 135 : 1009 -1012 .

6) Avner ED, Satz J, Plotkin SA: Hypoglycorrhacia in young infants with viral meningitis. $\mathrm{J}$ Pediatr $1975 ; 87: 833-834$.

7) Bacon CJ, Sims DG: Echovirus 19 infection in infants under six months. Arch Dis Child 1976; 51: 631-633.

8) Singer JI, Maur PR, Riley JP, Smith PB: Management of central nervous system infections during an epidemic of enteroviral aseptic meningitis. J Pediatr 1980 ; 96 : 559-563.

9) Chonmaitree T, Menegus MA, Powell KR: The clinical relevance of CSF viral culture: A two-year experience with aseptic meningitis in Rochester, New York. JAMA 1982 ; 247 : 18431847.

10) Wilden $S$, Chonmaitree $T$ : The importance of virology laboratory in the diagnosis and management of viral meningitis. Am J Dis Child 1987 ; $141: 454-457$.

11) Rotbart HA: Enzymatic RNA amplification of the enteroviruses. J Clin Microbiol 1990;28 :
438-442.

12) Bonadio WA, Stanco L, Bruce R, Barry D, Smith D: Reference values of normal cerebrospinal fluid composition in infants aged 0 to 8 weeks. Pediatr Infect Dis J $1992 ; 11$ : 589-591.

13) Rotbart HA : Diagnosis of enteroviral meningitis with the polymerase chain reaction. J Pediatr $1990 ; 117: 85-89$

14) Chapman NM, Tracy S, Gauntt CJ, Fortmueller $\mathrm{U}$ : Molecular detection and identification of enteroviruses using enzymatic amplification and nucleic acid hybridization. J Clin Microbiol $1990 ; 28: 843-850$.

15) Rotbart HA, Levin MJ, Murphy NL, Abzug MJ : RNA target loss during solid phase hybridization of body fluids - a quantitative study. Mol Cell Probes 1987 ; 1 : 347-358.

16) Wilfert CM, Zeller J: Enterovirus diagnosis. In: Medical virology IV (Maza L, Peterson EM, ed) 85-107, Lawrence Erlbaum Assiociates, London, 1985.

17) Schlesinger $\mathrm{Y}$, Sawyer MH, Storch GA : Enteroviral meningitis in infancy: Potential role for polymerase chain reaction in patient management. Pediatrics $1994 ; 94: 157-162$.

\title{
Diagnosis of Neonatal Enterovirus Meningitis by Reverse
} Transcription-Polymerase Chain Reaction

\author{
Hiroyuki YOSHIO, Masao YAMADA*, Yoriko YOKOI, Azusa IWAMOTO, \\ Makoto NAKAMURA \& Yumiko MIZOGUCHI \\ Department of Pediatrics, National Okayama Hospital \\ Department of Virology, Okayama University Medical School
}

We evaluated the potential clinical utility of a reverse transcription-polymerase chain reaction (RT-PCR) for neonatal enterovirus meningitis, comparing the results with viral culture and white blood cell (WBC) counts in the cerebrospinal fluid (CSF). Of the 41 cases of enteroviral infection, 31 cases $(76 \%)$ were finally diagnosed as meningitis by either viral culture, CSF WBC count or RT-PCR. Of those with culture positive and negative, the RT-PCR positive rates were $10(100 \%)$ and 6/13 (46\%), respectively. Of those with and without WBC increase in the CSF, the RT-PCR positive rates were 18/20 (90\%) and 5/14 (36\%), respectively. There was one RT-PCR positive case $(1 / 6,17 \%)$ among those with culture negative and no WBC increase in the CSF. RT-PCR performed on CSF is a sensitive and specific method for the diagnosis of neonatal enterovirus meningitis. 